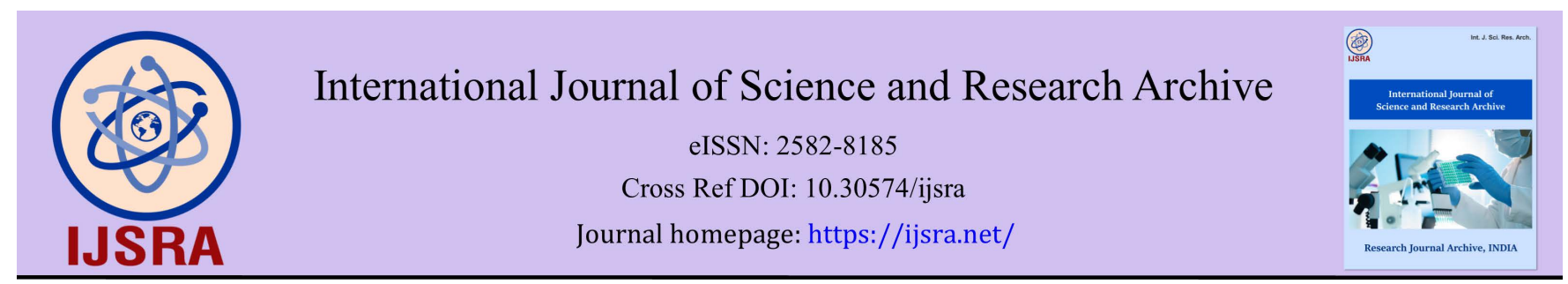

(REVIEW ARTICLE)

\title{
Pearl millet (Pennisetum glaucum) perspectives in Africa
}

\author{
Cheick Oumar Kangama * \\ Faculty of Agronomy and Animal Medicine (FAMA), University of Ségou, Segou, Mali.
}

International Journal of Science and Research Archive, 2021, 02(02), 001-007

Publication history: Received on 16 February 2021; revised on 21 March 2021; accepted on 23 March 2021

Article DOI: https://doi.org/10.30574/ijsra.2021.2.2.0043

\begin{abstract}
Pearl millet (Pennisetum glaucum) is an important grain crop for millions of poor farmers and grown in tropical in tropical semi-arid regions of the world primarily in Africa and Asia. Pearl millet is well adapted to production system characterized by low rainfall $(200-600 \mathrm{~mm})$, low soil fertility and high temperature. It is generally used as a temporary summer pasture crop or in some areas as a food crop.
\end{abstract}

Keywords: Pearl millet; Health

\section{Introduction}

Pearl millet is a small cereal with seed of $1.2-1.8 \mathrm{~mm}$ in diameter. It is a food that supplies a major proportion of calories and protein to large segment of population in the semi-arid tropical regions of Africa and Asia.

Pearl millet (Pennisetum glaucum) is the most widely grown type of millet. It has been grown in Africa and the India subcontinent since prehistoric times. The Centre of diversity and suggested area of domestication for the crop is in the Sahel zone of West Africa. Recent archaeobotanical research has confirmed the presence of domesticated pearl millet on the Sahel zone of northern Mali between 2500 and 2000 BC. Cultivation subsequently spread and moved overseas to India. The earliest archaeological records in India date to around $2000 \mathrm{BC}$ and it spread rapidly through India reaching south India by $1500 \mathrm{BC}$, based on evidence from the site of Hallur-cultivation also spread throughout eastern and southern parts of Africa. Pearl millet is widely grown in the northeastern part of Nigeria (especially in Borno and Yobe State). It is a major source of food to the local villagers of that region.

The crop grows easily in that region due to its ability to withstand harsh weather conditions like drought and flood. Records exist for cultivation of pearl millet in the United States in the 1850s and the crop was introduced into Brazil in the 1960s.

Pearl millet is a high nutritive-value summer-annual forage crop, popular among livestock producers for grazing, silage, hay, and green chop. Pearl millet can also be utilized as emergency forage that regularly performs well as an economical one-year crop option. It prefers well-drained soils, and at the seedling stage, it looks much like a corn or sorghum plant. Compared to sorghum, it is less tolerant of water logging and flooding. Pearl millet is indigenous African cereal that unlike wheat or rice are well adapted African semiarid and subtropical agronomic conditions.

Pearl millet is an important food across the Sahel region of Africa. It is a main staple (along with sorghum) in a large region of northern Nigeria, Niger, Mali and Burkina Faso.

\footnotetext{
* Corresponding author: Dr Cheick Oumar Kangama; Email: kangama31@yahoo.fr

Faculté d'Agronomie et de Médecine Animale (FAMA) / Université de Ségou. 
Water deficit is one of major abiotic factors limiting crop productivity in the semiarid and climate change is likely to make drought stress oven more severe in the future.

In Niger it is usually grown as an intercrop with sorghum and cowpea. The different growth habits, growth period and drought vulnerability of the three crops maximizing total productivity and minimizing the risk of total crop failure. It is often ground into flour, rolled into large balls, parboiled liquefied into a watery paste using fermented milk, and then consumed as a beverage. This beverage called « fura » in Hausa is a popular drink in northern Nigeria and southern Niger. Pearl millet is a widely food used in Borno State and its surrounding states, it is the most widely crop grown and harvested. There are many products that are gotten from the processing of the crop.

\section{Origin and Domestication}

The geographical origin and the Centre of domestication of Pearl millet are situated in West Africa. The plant was subsequently introduced into India, where the earliest archaeological records date back to 2000 BC (Gari, 2002, Oumar et al., 2008).

Based on the distribution of pearl millet throughout the continent, the uniform cradle of domestication is likely to be the regions of Mauritania, Senegal and West Mali.

Researchers believe that the development and spread of millet farming was spurred by the increasing desiccation of the Sahara Desert after 3000 BC.

Millet domestication followed the domestication of cattle in Africa by at least 1500 years and it is hypothesized that is because mobile pastoralist was better suited to the region prior to the onset of the desiccation.

By the second millennium BC, pearl millet is the primary food plant in Mali, Mauritania, Ghana, Burkina Faso and Cameroon.

\subsection{Taxonomy}

Pearl millet, Pennisetum glaucum is an annual, allogamous, cross-pollinated, and diploid Panicinae; section Pennisetum contains about 140 species.

The important wild relatives of cultivated pearl millet include the progenitor,

The four cultivated forms of pearl millet are typhoid's (found mainly in India and Africa), nigritarum (dominant in eastern Sahel), globasum (dominant in the western Sahel) and leonis (dominant on the West Africa coast) (Drunken et al, 1977, Ray et al; 1977; Syngenta, 2006).

\subsection{Common names}

Various common names of Pearl millet in different countries have been reported as mentioned below (from Wikipedia). Africa: Gerohatsii (Hausa), sanio, souna (Bambara).

Australia: Bulrush millet.

Brazil: Milheto Kaustubh

Dutch: parelgierst

English: Pearl millet

French: Millet perlé, mil penicillaire, petit mil, mil à chandelles.

India: Bajri, sajje in Kannada.

Italian: Miglio perlato

Russian: Proso

Spanish: Mijo perla, mijo Negro, Bajri

USA: Cattail millet (Pennisetum americanum)

\subsection{Characteristics}

With ovoid grain of 3-4 mm length pearl millet has the largest kernels of all varieties of millet (not including sorghum) which can be nearly white, pale yellow, brown, grey, slate blue or purple. The 1000 -seed weight can be anything from 2.5 to $14 \mathrm{~g}$ with a mean of $8 \mathrm{~g}$. The height of the plant ranges from 0.5-4 m. The inflorescence is usually greenish-yellow and it may be cylindrical throughout its length my taper at one or both ends. 


\subsection{Cultivation}

Pearl millet is well adapted to growing areas characterized by drought, low soil fertility and high temperature. It performs well in soils with high salinity or low $\mathrm{pH}$. It can be grown in areas where other cereal crops, such as maize or wheat, would not survive. Pearl millet is summer annual crop well-suited for double cropping and rotation.

Today pearl millet is grown on over $260.000 \mathrm{Km}^{2}$ of land worldwide. It accounts for approximately $50 \%$ of the total world production of millet.

\subsection{Nutrition}

In a 100-gram serving raw millet provides 378 calories and is a rich source (20\% or more of the Daily Value) of protein, dietary fiber, several B vitamins and numerous dietary minerals, especially manganese at $76 \%$. Raw millet is $9 \%$ water, $73 \%$ carbohydrates, $4 \%$ fat and $11 \%$ protein.

\subsection{Description, history and production}

Pearl millet is believed to have been domesticated over 5000 years ago in Africa (Andrews and Kumar, 1992) and is widely cultivated across the continent from the Sahelian (Sahara Desert margin) countries in West Africa. It is also widely cultivated in India and was probably introduced into that country some 3000 years ago.

Pearl millet is an annual plant about $2 \mathrm{~m}$ tall, with a cylindrical spike, $15-140 \mathrm{~cm}$ in length (National Research council, 1996). Pearl millet is uniquely well-adapted to harsh environmental conditions and can be cultivated in regions with very low annual rainfall, down to $250 \mathrm{~mm}$ and very high temperature of about $30^{\circ} \mathrm{C}$ in well-drained loam soil (National Research council, 1996).

Table 1 Top 10 millet producers- 2013

\begin{tabular}{|l|l|}
\hline Country & Production (Tones) \\
\hline India & 10.910 .000 \\
\hline Nigeria & $5.000 .000^{\mathrm{F}}$ \\
\hline Niger & $2.955 .000^{*}$ \\
\hline China & $1.620 .000^{\mathrm{F}}$ \\
\hline Mali & $1,152.000$ \\
\hline Burkina Faso & $1.109 .000^{*}$ \\
\hline Sudan & 1.090 .000 \\
\hline Ethiopia & 807.056 \\
\hline Chad & $582.000^{*}$ \\
\hline Senegal & 572.155 \\
\hline World & $\mathbf{2 9 . 8 7 0 . 0 5 8}$ \\
\hline $\begin{array}{l}\text { No symbol = official figure; } \\
\text { A = May include official, semiofficial or estimated data }\end{array}$ \\
Source $=$ Agriculture Organization of United Department. The statically Division
\end{tabular}

Pearl millet is one of the two major crops in the semiarid, impoverished, less fertile agriculture regions of Africa and Southeast Asia. Millet is not only adapted to poor, droughty and infertile soils, but they are also more reliable under these conditions than most other grain crops. This has, in part, made millet production popular, particularly in countries surrounding the Sahara in Western Africa.

Millets, however, do respond to high fertility and moisture. On per hectare basis, millet grain produced per hectare can two to four times higher with us of irrigation and soil supplements.

Improved breeds of millet improve their disease resistance and can significantly enhance farm yield productivity. There has been cooperation between poor countries to improve millet yield. For example, « Okashana1 » a variety developed 
in India from natural-growing millet variety in Burkina Faso, doubled yield. This breed was selected for trials in Zimbabwe. From there it was taken to Namibia, where it was released in 1990 and enthusiastically adopted by farmers.

India is the world's largest producer of millet in the 1970s; all of the millet crops harvested in India were used as a food staple by the 2000s. The annual millet production had increased in India, yet per capita consumption of millet had dropped as in between $50 \%$ to $75 \%$ in different regions of the country. As of 2005 , most millet produced in India is being used for alternative application such as livestock fodder and alcohol production.

In 2010, the average yield of millet crops worldwide was 0.83 ton per hectare.

\section{Research and Development}

Recently more production varieties of pearl millet have been introduced enabling farmers to increase production considerably.

To combat the problem of micronutrient malnutrition in Africa and Asia, a study of serving iron-biofortified pearl millet which is bred conventionally without genetic modification to a control group is proved to have higher level of iron absorbance by the group.

The most widely grown millet is pearl millet, which is an important sized crop in India and parts of Africa. Finger millet prosomillet and foxtail millet are also important crop species. Millet grains are high in carbohydrate, with protein content varying from 6 to 11 percent and fat varying from 1.5 to 5 percent. They are somewhat strong in taste and are mainly consumed in flatbreads and prepared an eaten much like rice.

\subsection{Distribution}

Pearl millet is native to the Sahel. It has spread across Africa from West to East and from there to Southern Africa. It was introduced to India in $3000 \mathrm{BC}$ and later to America, Brazil and Australia (Andrews et al 1992). It can be grown between 14 and $32^{\circ} \mathrm{N}$ and $\mathrm{S}$, and in every dry tropical area. It thrives well where other $\mathrm{C}_{4}$ cereals (maize, sorghum) cannot grow because of draught or heat.

It can be found in regions where annual rainfalls range from 125 to $900 \mathrm{~mm}$. Ideal growth temperature range from $21^{0}$ to $35^{\circ}$ C. Pearl millet is known to tolerate acid sandy soils and is able to grow on saline soils (FA0, 2009).

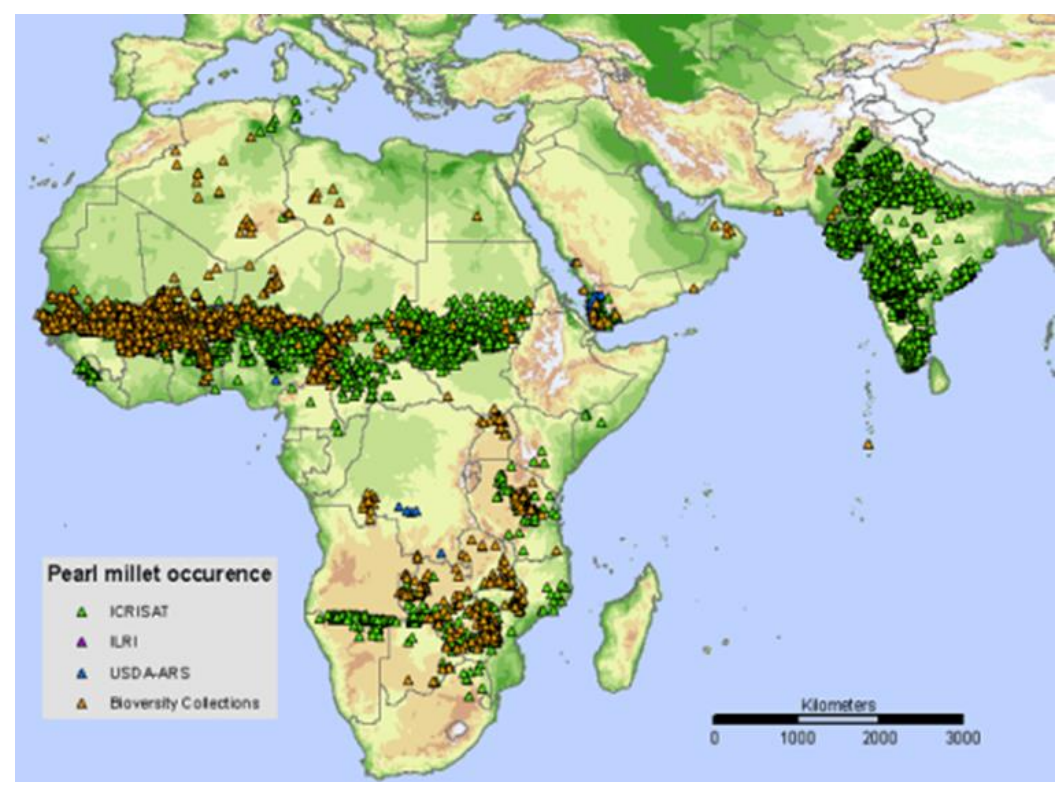

Figure 2 Mapping of pearl millet 


\subsection{Environmental impact}

Pearl millet is able to thrive in high salinity soils, where it maintains its good nutritive value. It can be used to increase the economic value of marginal saline soils in Egypt (Fahmy et al 2010).

\subsection{Why eat millet?}

Millets are highly nutritious, non-glutinous and non-acid forming foods. They are particularly high in minerals like iron, magnesium, phosphorous and potassium. For example, Finger Millet (Ragi in India) is the richest in calcium content about 10 times that of rice or wheat.

Millets are soothing and easy to digest. They are considered to be the least allergic and most digestible grains available compared to rice, especially polish rice, millet release lesser percentage of glucose and over a longer period of time. This lowers the risk of diabetes.

\subsection{Alcoholic beverages}

Millets are traditionally important grains used in braving millet beer in some culture. Various people in East Africa brew a drink from millet or sorghum known as ajono, a traditional brew.

The fermented millet is prepared in a large pot with hot water and people share the drink by sipping it through long straws.

Millet is also the base ingredient for the distilled liquor rahshi in Nepal and the indigenous alcoholic drink of the Sherpa.

\subsection{Health benefits of pearl millet}

The best health benefits of millet include its ability to protect the heart, prevent diabetes improve the digestive system, lower the risk of cancer, detoxify the body, improve respiratory health, boost the immune system, increase energy levels, and improve the muscle and nerve health.

\subsection{Millet nutrition facts}

Millet is important because of its uniquely high content of nutrients, including impressive starch levels, vitamin B, calcium, iron, potassium, zinc, magnesium and fats.

Furthermore, there are significant levels of contribute even more to the health benefits of this important grains.

\subsection{Protects heart health}

Millet is one of the best possible grains to add to your diet if you want to protect your heart. It is a rich source of magnesium, which is an important mineral for reducing blood pressure and the risk of heart attack or stroke, particularly in the case of atherosclerosis.

Millet is also a great source of potassium, which further keeps blood pressure low by acting as a vasodilator. Reducing your blood pressure and optimizing your circulatory system is one of the best ways to protect your cardiovascular health.

Furthermore, the plan lignam found in millet can be converted into animal lignam by the microflora in our digestive system and these animal lignam have been shown chronic diseases, like cancer and heart disease.

\subsection{Controls cholesterol levels}

Cholesterol levels go hand-in-hand with heart health, so the high fiber levels in millet make for an ideal cholesterollowering approach- Dietary fiber eliminates dangerous bad cholesterol from the system while promoting the effect of good cholesterol.

\subsection{Prevents diabetes}

Pearl millet has a very high amylase activity. Maltose and D-ribose are the predominant sugars in the flour, while fructose and glucose level are low (oshodi et al 1999). 
As most fiber-rich foods boast, millet can help move your gastrointestinal system along and eliminate problems like constipation, excess gas, bloating and cramping. By regulating your digestive processes, you also improve your nutrient retention and reduce your chance of more serious gastrointestinal and elimination of waste also help optimize your kidney, liver, and immune system health, as those organ systems are closely related to the body's metabolic activities.

Diabetes is a disease affecting millions of people around the world. Millet is a beneficial food staple in many countries (where diabetes is less frequently found). It is, perhaps, because one of the effects of millet is a reduced chance of type2 diabetes, thanks to the significant levels of magnesium found in it. Magnesium is considered a one of the important minerals for increasing the efficiency of insulin and glucose receptors in the body, thereby preventing these diseases. A $30 \%$ reduction in diabetes has been seen in the population that consumes a magnesium-rich diet.

\subsection{Aids in digestion}

As fiber-rich foods boast, millet can help move your gastrointestinal system along and eliminate problems like constipation, excess gas, bloating, and cramping. By regulating your digestive processes, you also improve your nutrient retention and reduce your chance of more serious gastrointestinal and elimination of waste also help optimize your kidney, liver, and immune system health, as those organ systems are closely related to the body's metabolic activities.

\subsection{Prevents cancer}

All millets are known to reduce the risk of cancer occurrence and pearl millet is no exception. Though scientists are not sure how this is they believe it has something to do with the high amount of magnesium.

Recent research has revealed fiber to be one of the best and easiest ways to prevent the onset of breast cancer in women. In fact, women can reduce their chances of breast cancer by more than $50 \%$ by eating more than 30 grams of fiber every day. Given that breast cancer I one of the most common and deadliest forms of cancer, this is an advice that every woman should consider.

\subsection{Detoxifies the body}

Many of the antioxidants in millet can clean up toxins from your body. Quercetin, curcumin ellagic acid, and various other beneficial catechins can help rid your system of any foreign agents and toxins by promoting proper excretion and neutralizing enzymatic activity I certain organs.

\subsection{Prevent asthma}

Research has come to light showing that millet can significantly improve the quality of life for people suffering from asthma since childhood and can also prevent it from developing in the first place. Although some of the evidence is controversial, it is shown that significantly less wheezing and asthma attacks (by more than 15\%) were seen in children who had a large intake allergen associated with asthma and wheezing, millet does not have the same components and hence, does not have this negative effect.

\subsection{Stomach ulcers treatment}

Pearl millet is recommended for curing stomach ulcers. The most common cause for stomach ulcers is excess acidity in the stomach after food intake. Pearl millet is one of the very few foods that turns the stomach alkaline and prevents formation of stomach ulcers or reduces the effect of ulcers.

\subsection{Energy}

Pearl millet is a rich source of energy $(361 \mathrm{kcal} / 100 \mathrm{~g})$ which is comparable with commonly consumed cereals such as wheat (346kcal/100g), rice (345kcal/100g), maize (125kcal/100g) and sorghum (349kcal/100g)

\section{Conclusion}

Pearl millet is important millet in arid regions of Africa and Asia. It is one of the coarse grain crops and is considered to be poor man's food. Pearl millet is an exceptionally adaptable crop in the harsh climatic and soil environment of semiarid West Africa.

Pearl millet will continue to be one of the most important crops contributing to food security in semi-arid West Africa, a major crop that provides food to millions of poor people in this region, and Stover as an animal feed and fuel source. 
Pearl millet biodiversity constitutes the ecological heritage of millions of small-scale and traditional farmers in SubSaharan Africa, playing a vital role in their agricultural systems, food security and livelihood.

\section{Compliance with ethical standards}

\section{Acknowledgments}

I am particularly grateful to my assistants who wanted to help me in the data collection. I thank the sotuba research station for their invaluable support.

\section{Disclosure of conflict of interest}

None.

\section{References}

[1] Vega JM, Yu W, Kennon AR, Chen X, Zhang Z J. Improvement of Agrobacterium-mediated transformation in Hi-II (Zea mays) using standard binary vectors. Plant Cell Rep. 2008; 27: 297-305.

[2] Lange M, Vince E, Moeller M G, Holm PB. Molecular analysis of transgene and vector backbone integration into the barley genome following Agrobacterium-mediated transformation. Plant cell Rep. 2006; 25: 815-820.

[3] Kononov ME, Bassuner B, Gelvin SB. Integration of T-DNA binary vector "backbone" sequences into the tobacco genome evidence for multiple complex patters of integration. Plant J. 1997; II: 945-957.

[4] Altpeter F, Baisakh N, Beachy R, Bock R, Capell T, Christou P, Daniell H, Datta K, Dix PJ, Faquet C, Huang N, Kohli A, Mooibroek H, Nicholson L. Nguyen T, Nugent G, Raemakers K, Romano A, Somers D, Stager E, Taylor N, Visser R. Particle bombardment and the genetic enhancement of crops, myths and realities. Mol Breed. 2005; 15: 305327.

[5] Lowe BA, Prakash NS, Way M, Mann MT, Spencer TM, Baddupalli RS. Enhanced single copy integration events in corn via particle bombardment using low quantities of DNA. Transgenic Res. 2009; 18: 831-840.

[6] Fu X, Duc L-T, Fontana S, Bong BB, Tinjuangjun P, Sudhakar D, Twyman RM, Christou P, Kohli A. Linear transgene constructs locking vector backbone sequences generate low-number transgenic plants wich simple integration patters. Transgenic Res. 2000; 9: 11-19.

[7] Kohli A, Leach M, Vain P, Laurie DA, Christou. Transgene organization rice engineered through direct DNA transfer supports a two-phase integration mechanism mediated by the establishment of integration hot spotsProc Natl Accad Sci USA. 1998; 95: 7203-7208.

[8] NE grotto D, Jolley M, Beer S, Wenck AR, Hansen G. The use of phosphonannose-isomerase as a selectable marker to recover transgenic maize plant (Zea mays L.). Plant cell Rep. 2000; 19: 798-803.

[9] Craw ford, Gary W, Gyoung-Ah Lee. Agricultural Origins in the Korean Peninsula Antiquity. 2003; 77(295): 8795.

[10] Adeola 0, Orban J. I chemical composition and nutrient digestibility of pearl millet (Pennisetum glaucum) fed to growing pigs. J cereal science. 1994; 22: 177-184.

[11] Anoma Chandrasekaran and Fereydoun Shahidi Bioactivities and Antiradical. Proprieties of Millet Grains and Hulls'. Agric.Food Chem. 2011; 59: 9563-9571. 